\title{
Profile of adolescent social media user in rural area
}

\author{
Patil M.A. ${ }^{1}$, Bharti H. ${ }^{2}$, Amte A. ${ }^{3}$, Singh B.K. ${ }^{4}$, Desai M. ${ }^{5}$ \\ ${ }^{1}$ Dr. Mohan A. Patil, Professor, Pediatrics, ${ }^{2}$ Dr. Hemant Bharti, Assistant Professor, Pediatrics, ${ }^{3}$ Dr. Amit Amte, \\ Practicing Pediatrician, ${ }^{4}$ Dr. Bhuvan Kumar Singh, Post Graduate Student, ${ }^{5}$ Dr. Manjiri Desai, Assistant Professor in \\ Statistics, ${ }^{1,2,4,5}$ all authors are affiliated with D.Y. Patil Medical College, Kolhapur, Maharashtra, India.
}

Corresponding Author: Dr. Hemant Bharti, Assistant Professor, Pediatrics, D.Y. Patil Medical College, Kolhapur, India.

\begin{abstract}
Background: With the widespread accessibility of internet in India over last decade, use of social media has become more popular especially in teenage children. Social media can be used for variety of reasons. It can be useful or may have adverse effects. In urban area use of social media is expected to be more however data regarding use of social media by adolescent children in this area is lacking. This study is conducted to know various aspects of social media use by adolescent children in rural part of Kolhapur district. Method: 650 students, with equal sex distributionin the age group of $15-18$ years studying in $11^{\text {th }} \& 12^{\text {th }}$ class from two rural areas of Kolhapur district were selected by simple random sampling technique. Data was collected by validated questionnaire. Data was analyzed by SPSS 23.0 version. Result: $87.86 \%$ rural adolescent children were found to use social media. Most of them were using it for entertainment and communication than for educational purpose. $30 \%$ children expressed negative feelings and more than half reported social media affecting their life style adversely. Conclusion: Accessibility to electronic gadgets, internet and social media is rapidly increasing to rural area. Along with good aspects of social media, negative aspects are also affecting rural adolescent children significantly. This highlight need for timely interventional strategies.
\end{abstract}

Keywords: Social media, Rural, Adolescent children

\section{Introduction}

Man is a social animal. Along with his basic needs of food, clothes and shelter he needs socialization. He needs to connect and communicate with others. Modes of communication have changed with the time. Communication via network using various electronic devices has replaced conventional personal modes of communication and has become integral part of modern era. According to Internet and Mobile Association of India's data, number of internet user in India has reached 478 million by June 2018. Any website that allows social interaction is social media [1].

Most of the world's population is involved in such social networking, adolescents and young adults being most actively involved. Young children are not far from such practices. Time spent by children with use of social media, is matter of concern all over the world. Social media per say are not good or bad. Their good or bad use decides the result. Data all over the world indicates significant number of children have easy

Manuscript received: $2^{\text {nd }}$ January 2019

Reviewed: $8^{\text {th }}$ January 2019

Author Corrected: $12^{\text {th }}$ January 2019

Accepted for Publication: $15^{\text {th }}$ January 2019 access to electronic devices like television, cell phones, computers, tablets, along with internet connection. It makes them easy for use of social media by means of use of Face book, Twitter, WhatsApp, email, YouTube, blogs and similar applications [1-3].

Positive effects of social media can be many. It can be a good mode of education and distant learning. Similarly it can be a new medium of learning opportunities, creativity, homework and group project. It can help adolescents to connect with peers and share their knowledge, thoughts, art, music and games. It will foster their individual identity and social skills. It also gives opportunity for exercising and gaming. However inappropriate and excessive use of social media significantly contributes to deleterious consequences in children.

High incidence of psychological distress in users of social media for more than two hrs has shown to have effect on cognitive, social, behavioral development, sleep disturbance, decreased school performance, social isolation, altered sex behavior and substance abuse[4- 
6]. These children are prone for attention deficit and hyperactivity disorders. Lack of physical activity in association with high caloric low nutritious food intake, leads to obesity and its consequences. With effect on spinal curvature one can have postural problems like kyphosis, scoliosis. Cyberbullying and online harassment may lead to severe psychological stress. It may add to real life aggression and violence [7-9]. Social media can create unrealistic expectations about body image leading to development of eating disorders.

Consequences of use of social media are going to vary regionally due to variations in availability of electronic gadgets, internet connections, knowledge about social media and parental supervision. Variations are also expected in urban and rural setups.

As adolescence is an age group where children are undergoing extensive physical, mental \& emotional changes, effects of social media are going to affect them the most. In view of all these factors this study was planned to get some baseline data regarding use of social media by adolescent children in rural area.

\section{Material \& Methods}

Two rural villages $25 \mathrm{~km}$ from Kolhapur cityof western part of Maharashtra state in India, Minche and Bhogavati, one on the east and one on the west of Kolhapur city respectively were selected as representative rural area.

Anobservational study was conducted after approval from ethical committee. Students between the age group of 15 to 18 years willing to participate in the study were included in the study. $11^{\text {th }}$ and $12^{\text {th }}$ standard junior college students with age 15 to 18 years participated in this study with their informed consent.

Data was collected from 325 students from each village. Total 650 students, almost equal boys and girls, 332 and 318 respectively participated in the study. The simple random sampling technique was applied to select students and the data was collected through a questionnaire. Confidentially of the data was kept. Data was filled in the MS Excel sheet and analyzed by SPSS 23.0 version method.

\section{Results}

Table-1: Demographic profile and access to social media.

\begin{tabular}{|l|l|l|}
\hline Variable & & Results \\
\hline Total participants & & 650 \\
\hline Age & & Mean age- 16.6 years \\
\hline Gender & & M:F- 332: 318 (51\%: 49\%) \\
\hline Access to electronic media & & $641 / 650(99 \%)$ \\
\hline Own a cell phone & & $477 / 650(73.42 \%)$ \\
\hline Access to cell phone & & $565 / 650(86.87 \%)$ \\
\hline Access to internet connection & Total & $571 / 650(87.82 \%)$ \\
& Mobile data, & $540 / 650(83.15 \%)$ \\
& living room, & $234 / 650(36 \%)$ \\
& Bedroom, & $206 / 650(31.65)$ \\
& School/college, & $323 / 650(49.7 \%)$ \\
& Net café & $300 / 650(46.2 \%)$ \\
\hline Use of social media & & $571 / 650(87.82 \%)$ Yes \\
\hline Social media details & WhatsAap & $463 / 571(81.14 \%)$ \\
& Face book & $314 / 571(54.94 \%)$ \\
& Twitter & $60 / 571(10.5 \%)$ \\
& You tube & $401 / 571(70.61 \%)$ \\
& Email & $371 / 571(65.34 \%)$ \\
& Other & $51 / 571(9 \%)$ \\
\hline
\end{tabular}

Total numbers of participant children were 650. Almost equal number of boys and girls, boys 332(51\%) and girls $318(49 \%)$ participated in the study. Their mean age was 16.6 yrs. Majority of children were in contact with various modes of electronic gadgets. Main electronic media were radio $67.35 \%$, television $96.11 \%$, cell phone $86.87 \%$, computer 
network $49.69 \%$, videogames $35.12 \%$, movies $83.45 \%$ and other $32.74 \%$. In spite being rural area, $86.87 \%$ children had access to cell phones, $73.42 \%$ owned their cell phones. Average $87.82 \%$ children had access to internet, most having internet access at multiple sites like mobile data $83.15 \%$, living room $36 \%$, bedroom $31.65 \%$, school $/$ college $49.7 \%$, net café $46.2 \%$, other $5.15 \%$; mobile data being the commonest. $87.82 \%$ children were using social media, with quite significant numbers were using multiple modes of social media like whatsAap $81.14 \%$, face book $54.94 \%$, twitter $10.5 \%$, you tube $70.61 \%$, email $65.34 \%$ and other $9 \%$.

Table-2: Details of use of social media.

\begin{tabular}{|c|c|c|}
\hline Variable & & Results \\
\hline Daily time spent on social media & $\begin{array}{l}<\text { halfhour } \\
\text { Half to } 1 \text { hour } \\
1 \text { to } 2 \text { hours } \\
2 \text { to } 4 \text { hours } \\
>4 \text { hours }\end{array}$ & $\begin{array}{l}82 / 571(14.3 \%) \\
124 / 571(21.7 \%) \\
190 / 571(33.4 \%) \\
120 / 571(21 \%) \\
55 / 571(9.6 \%)\end{array}$ \\
\hline Purpose of using social media & $\begin{array}{l}\text { IP communication, } \\
\text { Entertainment, } \\
\text { Education/group discussion } \\
\text { Research } \\
\text { Video games } \\
\text { Distant learning } \\
\text { Exercising /gaming, } \\
\text { Art/music games }\end{array}$ & $\begin{array}{l}335 / 571(58.6 \%) \\
451 / 571(78.99 \%) \\
72 / 571(12.68 \%) \\
168 / 571(29.45 \%) \\
61 / 571(40.76 \%) \\
228 / 571(39.95 \%) \\
253 / 571(44.32 \%) \\
26 / 571(4.5 \%)\end{array}$ \\
\hline Time to go to bed & $\begin{array}{l}<9 \mathrm{pm} \\
9-10 \mathrm{pm} \\
10-11 \mathrm{pm} \\
11-12 \mathrm{pm} \\
>12 \text { midnight }\end{array}$ & $\begin{array}{l}254 / 571(44.49 \%) \\
297 / 571(52.14 \%) \\
9 / 571(1.57 \%) \\
8 / 571(1.35 \%) \\
3 / 571(0.45 \%)\end{array}$ \\
\hline Use of SM before going to bed & & $540 / 571(94.64 \%)$ \\
\hline Age of first use of SM & $\begin{array}{l}<5 \text { years } \\
5-10 \text { years } \\
10-15 \text { years } \\
15-18 \text { years }\end{array}$ & $\begin{array}{l}15 / 571(2.55 \%) \\
6 / 571(1.12 \%) \\
124 / 571(21.69 \%) \\
426 / 571(74.64 \%)\end{array}$ \\
\hline Frequency of checking updates on SM & $\begin{array}{l}1-3 \text { hours } \\
3-6 \text { hours } \\
6-12 \text { hours } \\
\text { once in } 24 \text { hours }\end{array}$ & $\begin{array}{l}107 / 571(18.68 \%) \\
143 / 571(25.11 \%) \\
101 / 571(17.75 \%) \\
220 / 571(38.46 \%)\end{array}$ \\
\hline
\end{tabular}

Daily time spent on social media was< half hour $14 \%$, half to1 hr 22\%, 1-2 hrs 34\%, 2-4 hrs 21\%, > $4 \mathrm{hrs} 9 \%$. Analysis of purpose of use of social media shows, it was used for interpersonal communication $58.6 \%$, entertainment $78.99 \%$, education and group project $12.68 \%$, research $29.45 \%$, videogames $40.86 \%$, distant learning $39.95 \%$, exercising \& gaming $44.32 \%$, sharing art and music $4.5 \%$.

Most common use was for entertainment and interpersonal communication. Use of social media for educational purpose was seen in smaller percentage of children. Time to go to bed at night was found as $<9 \mathrm{pm} 44.49 \%, 9-10 \mathrm{pm} 52.14 \%, 10-$ $11 \mathrm{pm} 1.57 \%, 11-12 \mathrm{pm} 1.35 \%$ and $>12$ midnight $0.45 \%$.

Though majority of children go to bed at night before $11 \mathrm{pm}, 94.64 \%$ of them use social media before going to bed. Age of using social media for the first time was found to be $<5$ yrand $15-18$ yr $74.64 \%$.

Frequency of checking phone \& mail was $1-3 \mathrm{hr} 18.68 \%, 3-6 \mathrm{hr} 25.11 \%, 6-12 \mathrm{hr} 17.75 \%$ and once in $24 \mathrm{hrs} 38.46 \%$. More than half of the children checked their electronic devices frequently for latest messages. 
Table-3: Social media and its effects.

\begin{tabular}{|c|c|c|}
\hline Variable & & Results \\
\hline Daily hours spent on physical exercise & $\begin{array}{l}<\text { half hr } \\
\text { Half }-1 \mathrm{hr} \\
1-2 \mathrm{hrs} \\
>2 \mathrm{hrs}\end{array}$ & $\begin{array}{l}98 / 571(15.08 \%) \\
212 / 571(32.62 \%) \\
152 / 571(23.38 \%) \\
188 / 571(28.92 \%)\end{array}$ \\
\hline Feeling with use of SM & $\begin{array}{l}\text { Happy } \\
\text { Normal } \\
\text { Nervous } \\
\text { Anxious } \\
\text { Lonely } \\
\text { Low self esteem } \\
\text { Depression }\end{array}$ & $\begin{array}{l}463 / 571(81.1 \%) \\
491 / 571(85.95 \%) \\
494 / 571(86.5 \%) \\
45 / 571(7.8 \%) \\
71 / 571(12.46 \%) \\
4 / 571(0.7 \%) \\
56 / 571(9.83 \%)\end{array}$ \\
\hline Affection due to SM & $\begin{array}{l}\text { Sleep pattern } \\
\text { Eating habit } \\
\text { Weight } \\
\text { Ideas about body } \\
\text { imageAggression and } \\
\text { violencePhysical activity } \\
\text { Food and beverage choice } \\
\text { Direct interpersonal } \\
\text { communication } \\
\text { Tobacco chewing and alcohol } \\
\text { habit } \\
\text { Smoking gutka } \\
\text { Source of information about sex }\end{array}$ & $\begin{array}{l}350 / 571(61.33 \%) \\
231 / 571(40.53 \%) \\
147 / 571(25.75 \%) \\
293 / 571(51.37 \%) \\
224 / 571(39.17 \%) \\
392 / 571(68.68 \%) \\
250 / 571(43.75 \%) \\
324 / 571(56.76 \%) \\
192 / 571(33.63 \%) \\
11 / 571(2 \%) \\
217 / 571(37.95 \%)\end{array}$ \\
\hline Attractive content of SM & $\begin{array}{l}\text { Education } \\
\text { Distant learning } \\
\text { Peer communication Sending } \\
\text { photo and video } \\
\text { Entertainment } \\
\text { Videogames } \\
\text { Sexting }\end{array}$ & $\begin{array}{l}504 / 571(88.31 \%) \\
329 / 571(57.54 \%) \\
295 / 571(51.69 \%) \\
430 / 571(75.23 \%) \\
457 / 571(80 \%) \\
201 / 571(35.23 \%) \\
79 / 571(13.85 \%)\end{array}$ \\
\hline
\end{tabular}

Time spent on physical exercise was reported as < half hr $15.08 \%$, half to $1 \mathrm{hr} 32.62 \%, 1-2 \mathrm{hr} 23.38 \%$, and $>2 \mathrm{hr} 28.92 \%$. Almost $75 \%$ could spend more than half an hour daily for exercise; one third could spend more than 2 hours. There was mixed and multiple response for the question how they feel about use of social media. It was found as happy $81.1 \%$, normal $85.95 \%$, nervous $86.5 \%$, anxious $7.8 \%$, lonely $12.46 \%$, low self esteem $0.7 \%$ and depression $9.83 \%$. Many children reported multiple feelings.

Though 70\% children enjoyed using social media, remaining 30\% reported negative feelings like nervousness, anxiety, loneliness and depression. Analysis of how social media affected showed, it affected their sleep pattern $61.33 \%$, eating habit $40.53 \%$, weight $25.75 \%$, ideas about body image $51.37 \%$, aggression and violence $39.17 \%$, physical activity $68.68 \%$, food and beverage choice $43.75 \%$, direct interpersonal communication $56.76 \%$, tobacco chewing and alcohol habit $33.63 \%$, smoking gutka $2 \%$, and source of information about sex $37.95 \%$. Significant number of children felt that use of social media affected their lifestyle adversely.

Fortunately effect on dangerous habits like smoking and gutka was reported by only small percentage of children $2 \%$. On questing which use of social media children found attractive, it received multiple responses. They were education $88.31 \%$, distant learning $57.54 \%$, peer communication $51.69 \%$, sending photo and video $75.23 \%$, entertainment $80 \%$, videogames35.23\% and sexting $13.85 \%$. Entertainment and communication constitute leading answers. Though educational purpose was reported by $74 \%$, it didn't reflect in their actual use. 


\section{Discussion}

There is general assumption that children in rural area have some disadvantage in many areas as compared to their urban counterpart. This study doesn't endorse this assumption as far as availability and use of commonly used electronic gadgets and social media. $86.87 \%$ children in rural study population had access to cell phones, $73.42 \%$ owned their cell phones and majority of them had access to other forms of electronic gadgets.

These findings are similar with findings of Annesh Bhat et al [10]. $88 \%$ children reported to have internet accessibility with significant number having accessibility at multiple sites. Especially connectivity to net at bedroom makes them susceptible for excessive use of social media, late nightwaking, sleep disturbances, and late morning awakening.

WhatsAap, you tube, face book, email were common modes of use of social media with other modes like twitter, instagram used to a lesser extent. Daily time spent on social media was more than one hour in $64 \%$ children; $9 \%$ of them spending more than four hours. It is really a matter of concern.

Children were found to have entertainment as priority for use of social media followed by interpersonal communication. Use of social media for educational purpose, distant learning, research and health was reported by less number of children. In spite of majority of children reporting to go to bed before $11 \mathrm{pm}$, most of them use social media before going to bed was matter of concern.

Use of electronic media before going to bed is associated with multiple health problems like altered sleep behavior, externalizing behavior, depressed mood, decline in self-esteem and coping; hence strongly discouraged. [11-14]. Two third of children experienced their first exposure to social media between the age of 15-18 years. Half of the students checked their mobiles, mails once in a day while remaining half checked more frequently than once in a day.

Good part of study was in spite of easy accessibility of electronic gadgets and internet connection almost 75\% children could spend $>$ half an hour daily for exercise, one third could spend $>2$ hours. $70 \%$ children enjoyed their social media use.

They felt happy about it. Rest $20 \%$ expressed mixed feelings like loneliness, nervousness, depression; which should be a matter of concern. Use of social media did affect certain areas of children like sleep pattern, food habits, direct interpersonal relations, behavior and physical activities. Response percentage for these negative aspects is alarming.

Similar findings were reported in Indian adolescent childrenalong with other behavioral problems, decreased privacy, living in virtual world than real world, affecting scholastic performance and eating habits. However most of these studies were done in urban area [15]. Analysis of how social media affected various aspects of daily life showed significant findings.

Social media affected their sleep pattern, eating habit, weight, ideas about body image, aggression and violence, physical activity, food \& beverage choice, direct interpersonal communication, tobacco chewing and alcohol habit in almost more than half children.

Studies regarding tobacco use in India indicate most susceptible time for initiating tobacco use in India is during adolescence and early adult hood [16]. Similar findings highlighted influence of social media alcohol marketing on youth alcohol use behavior in India [17].

These findings raise concern regarding how social media is adversely affecting healthy life style activities of children at young age. Similar findings were reported in other studies affecting various areas under study [11, 18-22].

Attractive feature of social media was reported as entertainment and interpersonal communication. Though use of social media for educational purpose was appreciated by significant number of children, it didn't reflect in their practical behavior.

Findings from the current study suggests use of social media for constructive positive purpose, is not being used in practice by rural adolescent population under study. Negative aspects of social media use raises concern [23,24].

Use of social media should be keenly monitored and intervened since young age by parents as suggested by American Academy of Pediatrics [14,25-27].

Limitations of study: Representative sample is small and it's from only two rural areas. Finding of the study cannot be generalized. As regional variations are expected in use of social media, multicentric studies will be more conclusive. 


\section{Conclusions}

Rapidly increasing access to internet and exponential growth in the use of social media by Indian youth is progressing from urban area to rural area. Use of social media for entertainment and communication than for educational and personality development purpose raises concern. Negative effects of social media use are reflecting in rural adolescent children also. This highlights need for timely interventional strategies in at risk adolescent children.

What is known: Easy accessibility of urban youth to electronic media and extensive use of social media is known.

What this study adds: Negative effects of use of social media are affecting rural youth to significant extent. There is need for timely interventional strategies for high risk adolescent children.

Contributors: MAP designed the study, drafted manuscript and reviewed the literature. $\mathrm{HB}$ and $\mathrm{AP}$ collected data. BK compiled the data, MD analyzed the data. All authors approved the final manuscript.

Funding: Nil, Conflict of interest: None initiated, Perission from IRB: Yes

\section{References}

1. O'Keeffe GS, Clarke-Pearson K; Council on Communications and Media. The impact of social media on children, adolescents, and families. Pediatrics. 2011 Apr;127(4):800-4. doi: 10.1542/peds.2011-0054. Epub 2011 Mar 28.

2. Maeve Duggan, Joanna Brenner. The Demographics of social Media Users 2012. Pew Research Center's Internet \& American Life Project. 14 February 2013. Available from: URL:http://www.pewinternet.org

3. Available from:URL: http://www.internetworld stats. $\mathrm{com} /$ stats.htm. Internet Users in the World by Geographic Regions- June 30, 2018. Accessed January 7, 2019.

4. Richards D, Caldwell PH, Go H. Impact of social media on the health of children and young people. J Paediatr Child Health. 2015 Dec;51(12):1152-7. doi: 10.1111/jpc.13023. Epub 2015 Nov 26.

5. Surwase K, Bagdey P, Adikane H. Prevalence and Associated Risk Factors of Internet Addiction in College Going Students in Nanded city. Natl J Community Med 2017; 8(5):213-218.
6. Ray M, Jat KR. Effect of electronic media on children. Indian Pediatr. 2010 Jul;47(7):561-8.

7. Wilson BJ. Media and children's aggression, fear, and altruism. Future Child. 2008 Spring;18(1):87-118.

8. Sampasa-Kanyinga H, Lewis RF. Frequent Use of Social Networking Sites Is Associated with Poor Psychological Functioning Among Children and Adolescents. Cyberpsychol Behav Soc Netw. 2015 Jul; 18 (7): 380-5. doi: 10.1089/cyber.2015.0055.

9. Goel D, Subramanyam A, Kamath R. A study on the prevalence of internet addiction and its association with psychopathology in Indian adolescents. Indian $\mathbf{J}$ Psychiatry. 2013 Apr;55(2):140-3. doi: 10.4103/00195545.111451.

10. Bhat A, Cherian A, Thomas C, et al. Problematic internet use among Indian adolescents: finding from a sample of undergraduate students. J. Evolution Med. Dent. Sci. 2016;5(53):3491-3495, DOI: 10.14260/ jemds / 2016/806

11. Ray M, Jat KR. Effect of electronic media on children. Indian Pediatr. 2010 Jul;47(7):561-8.

12. Lynette Vernon, Kathryn L. Modecki, Bonnie L. Barber. Mobile Phones in the Bedroom: Trajectories of Sleep Habits and Subsequent Adolescent Psychosocial Development. Child Development: Vol 89, No 1 Jan/ Feb 2018: 66-77.

13. Nicola Hughes, Jolanta Burke .Sleeping with the frenemy: How restricting 'bedroom use' of smartphones impacts happiness and wellbeing. Computers in Human Behavior. Volume 85, August 2018: 236-244.

14. Policy statement, American Academy of Pediatrics. Children, Adolescents and the Media. PEDIATRICS Volume 132, Number 5, November 2013: 958- 961. doi:10.1542/peds.2013-2656.

15. Sanjeev Davey, Anuradha Davey. Assessment of Smartphone Addiction in Indian Adolescents: A Mixed Method Study by Systematic-review and Meta-analysis Approach. Int J Prev Med. 2014 Dec; 5(12): 1500-1511

16. Alpesh Shankerlal Patel, Raman D Damor. A cross section study on tobacco consumption practice in school going adolescent male of Jamnagar city, Gujarat, India. ijcmph Vol 5 No.3(2018) March 2018: 933-938. DOI:http://dx.doi.org/10.18203/2394-6040.ijcmph 2018 0478 . 
17. Gupta H, Lam T, Pettigrew S, et al. The association between exposure to social media alcohol marketing and youth alcohol use behaviors in India and Australia. BMC Public Health. 2018 Jun 13;18(1):726. doi: 10. 1186/s12889-018-5645-9.

18. V Goswami, D Singh (2016), Internet Addiction among Adolescents:A Review of the Research, International Journal of Indian Psychology, Volume 3, Issue 3, No. 11, DIP: 18.01.194/20160303, ISBN: 978$1-365-21307-6$

19. An, Jing MM; Sun, Ying MD; Wang Xi MM; Tao, Fangbiao MD, PhD. Associations Between Problematic Internet Use and Adolescents' Physical and Psychological Symptoms: Possible Role of Sleep Quality. Journal of Addiction Medicine: July/August 2014 - Volume 8 - Issue 4 - p 282-287. doi: 10.1097 / ADM.0000000000000026

20. Vivek Agarwal, Saranya Dhanasekaran. Harmful Effects of Media on Children and Adolescents. J. Indian Assoc. Child Adolesc. Ment. Health 2012; 8(2):38-45

21. Bányai F, Zsila Á, Király O, et al. Problematic Social Media Use: Results from a Large-Scale Nationally Representative Adolescent Sample. PLoS One. 2017 Jan 9;12(1):e0169839. doi: 10.1371/journal. pone.0169839. eCollection 2017.
22. Victor C. Strasburger, Amy B. Jordan, Ed Donnerstein. Health Effects of Media on Children and Adolescents. Pediatrics. April 2010, Volume 125/ Issue 4: 756-767.

23. Bianca S. Honnekeri, Akhil Goel, Maithili Umate, Nilesh Shah, Avinash DeSousa. Social anxiety and Internet socialization in Indian undergraduate students: An exploratory study. Asian Journal of Psychiatry. Volume 27, June 2017: 115-120.

24. Yatan Pal Singh Balhara, M. Harshwardhan, Rajeev Kumar, Shalini Singh. Extent and pattern of problematic internet use among school students from Delhi: Findings from the cyber awareness programme. Asian Journal of Psychiatry: Volume 34, April 2018, $38-42$.

25. Suhail K, Bargees Z. Effects of excessive Internet use on undergraduate students in Pakistan. CyberpsycholBehav. 2006 Jun;9(3):297-307.

26. AAP Council on Communications and media. Media and Young Minds. Pediatrics, 2016: 138 (5): e20162591. DOI: 10.1542/peds.2016-2591

27. Aysu Turkmen Karaagac. Undesirable Effects of Media on Children: Why limitation is Necessary? Indian Pediatr 2015:52: 469-471.

\section{How to cite this article?}

Patil M.A, Bharti H, Amte A, Singh B.K, Desai M. Profile of adolescent social media user in rural area. Int J Pediatr Res. 2019;6(01):22-28.doi:10.17511/ijpr.2019.i01.04 